\title{
Descending Spinal Pathway Subserving the Adrenaline Secretion of the Adrenal in Dogs
}

\author{
By \\ Tatuzi Suzuki, Ikuro Tanaka, Chikamasa Ninagawa, \\ （鈴木 達二）（田中育郎） (䗄川親 正) \\ Teruo Nakamura and Shigemi Fujisaki \\ （中村 照夫）(藤崎 茂已) \\ From the Department of Physiology, Nagasaki University \\ School of Medicine, Nagasaki
}

(Received for publication, December 20, 1957)

Tournade, Hermann, Malmejac and Jourdan ${ }^{11}$ studied the descending spinal pathway of secretory fibers to the adrenal medulla. In their experiments the method of suprareno-jugular anastomosis was employed and the hemisection of the spinal cord was made at the level of Th2. The faradization of the spinal cord above the site of hemisection resulted in an increase in the adrenaline secretion from the ipsilateral as well as from the contralateral adrenal gland. From these results it was concluded by them that the adrenalino-secretory fibers partly passed down directly the spinal cord and partly decussated. Evidence given by them, however, is to be brought into question, since the possibility of the current spread to just below the site of section cannot be ruled out.

Here, the adrenalino-secretory action of insulin hypoglycemia is recalled. The augmentation of adrenaline secretion induced by insulin hypoglycemia is well established. It was proved by Sato, Kanowoka and $\mathrm{Ohmi}^{2}$ that this augmentation was wholly abolished by the transection of the spinal cord at the lower cervical segments. And it was concluded that insulin hypoglycemia increased the adrenaline secretion in acting on the center situated above the level of the section.

In the present investigation we have examined in the first place whether the findings of Sato et al. can be duplicated by our hands. Our success in the duplication led us to apply insulin hypoglycemia to the study of the descending spinal pathway. Experiments were performed in an attempt to know how the hemisection of the spinal cord at the lower cervical level acts on the secretion of adrenaline after insulin from each of both adrenal glands. 


\section{EXPERIMENTAL}

\section{Methods}

Unanesthetized dogs were experimented on. The adrenal venous blood was sampled by means of the lumbar route method of Satake, Sugawara and Watanabe. ${ }^{3)}$ The adrenaline content of the blood specimens was estimated by the rabbit intestinal segment method, adrenaline (Sankyo) being taken as the standard. The blood sugar content was determined by the method of Hagedorn and Jensen. Insulin was injected intravenously in a dose of 7 units per $\mathrm{kg}$. of body weight.

In the present investigation 2 sets of experiments were performed.

In the first set, the total section of the spinal cord was made at the level of C7-C8 under ether anesthesia and 2 days later the experiments were done without anesthetizing the animals. The adrenal venous blood from the left gland was sampled.

In the second set, the dorsal spinal roots of Thll-L3 were cut under ether anesthesia in order to perform experiments without anesthetizing or evoking any pain. About 3-14 weeks later the hemisection of the spinal cord was made in the left side at the level of C7-C8 under ether anesthesia and on the following day or 2 days later the experiments were performed without anesthesia. In these dogs the adrenal venous blood specimens were sampled from each of both adrenal glands. At the termination of experiments the spinal cord from the lower cervical to the upper thoracic segments was removed and the site of hemisection was verified histologically.

\section{Results}

(1) Experiments in dogs subjected to the spinal cord transection.

Expcriments were performed in 2 dogs. The results are presented in Table I.

In Exp. 1 the blood sugar content before insulin was 0.097-0.099\%. After the insulin injection it decreased step by step. At 1 hour it reached $0.059 \%$. Two hours after injection it was measured as $0.048 \%$ and 30 minutes later it was $0.039 \%$. The adrenaline secretion rate before insulin was $0.01 \mu \mathrm{g}$. per $\mathrm{kg}$. of body weight per minute. After insulin there was no increase in the adrenaline secretion. It was measured as $0.005-0.008 \mu \mathrm{g}$.

In Exp. 2 the blood sugar level before insulin was $0.077-0.079 \%$. On receiving insulin it decreased and $0.034 \%$ was reached 2 hours after insulin. The rate of adrenaline secretion before insulin was $0.01-0.02 \mu \mathrm{g}$. per kg. per minute. After insulin it remained unaltered.

Thus it was proved that the acceleration of adrenaline secretion causable by insulin hypoglycemia was wholly prevented by the total section of the spinal cord at the lower cervical segments. 
TABLE I

Adrenaline Secretion Rate after Insulin in Dogs

Subjected to the Spinal Cord Transection

\begin{tabular}{|c|c|c|c|c|c|c|c|}
\hline 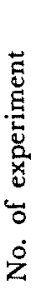 & 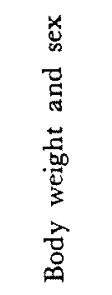 & 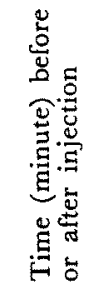 & 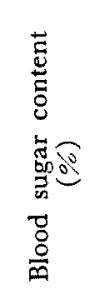 & 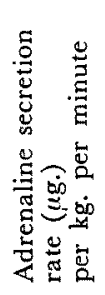 & 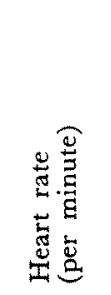 & 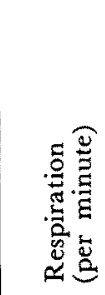 & 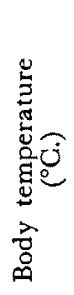 \\
\hline \multirow[t]{2}{*}{1} & \multirow[t]{2}{*}{$\underset{\widehat{\delta}}{15.9 \mathrm{~kg} .}$} & $\begin{array}{c}\text { Before } \\
20 \\
5\end{array}$ & $\begin{array}{c}0.099 \\
0.097 \\
\text { Injection }\end{array}$ & $\begin{array}{c}0.01 \\
0.01 \\
\text { insulin }\end{array}$ & $\begin{array}{c}82 \\
82 \\
\text { units per }\end{array}$ & $\begin{array}{l}16 \\
\text { kg.) }\end{array}$ & $\begin{array}{l}37.0 \\
36.9\end{array}$ \\
\hline & & $\begin{array}{r}\text { Atter } \\
20 \\
40 \\
60 \\
90 \\
120 \\
150\end{array}$ & $\begin{array}{l}0.072 \\
0.068 \\
0.059 \\
0.057 \\
0.048 \\
0.039\end{array}$ & $\begin{array}{l}0.008 \\
0.007 \\
0.007 \\
0.007 \\
0.008 \\
0.005\end{array}$ & $\begin{array}{l}84 \\
80 \\
78 \\
78 \\
70 \\
60\end{array}$ & $\begin{array}{l}22 \\
18 \\
20 \\
20 \\
22 \\
20\end{array}$ & $\begin{array}{l}36.9 \\
36.6 \\
36.4 \\
36.2 \\
35.2 \\
34.4\end{array}$ \\
\hline \multirow[t]{2}{*}{2} & \multirow[t]{2}{*}{$\underset{\$}{17.5 \mathrm{~kg} .}$} & $\begin{array}{c}\text { Before } \\
25 \\
5\end{array}$ & $\begin{array}{c}0.077 \\
0.079 \\
\text { Injectio }\end{array}$ & $\begin{array}{c}0.02 \\
0.01 \\
\text { insulin }\end{array}$ & $\begin{array}{c}58 \\
60 \\
\text { units per }\end{array}$ & $\begin{array}{r}19 \\
22\end{array}$ & $\begin{array}{l}31.1 \\
31.2\end{array}$ \\
\hline & & $\begin{array}{r}\text { After } \\
60 \\
90 \\
120 \\
150\end{array}$ & $\begin{array}{l}0.045 \\
0.039 \\
0.034 \\
0.039\end{array}$ & $\begin{array}{l}0.02 \\
0.02 \\
0.02 \\
0.02\end{array}$ & $\begin{array}{l}58 \\
50 \\
46\end{array}$ & $\begin{array}{l}29 \\
31 \\
23\end{array}$ & $\begin{array}{l}31.7 \\
31.8 \\
31.5\end{array}$ \\
\hline
\end{tabular}

(2) Experiments in dogs subjected to the spinal cord hemisection.

Experiments were performed in 4 dogs. The data are displayed in Table II. In examining histologically the site of hemisection after each experiment, it was found that in Exps. 5 and 6 the section of the left lateral half of the spinal cord was complete and in Exps. 3 and 4 a small portion of ventral column in the left side was remained uninjured.

In Exp. 3 the blood sugar content before insulin was $0.120-0.124 \%$. After insulin injection it decreased noticeably. Forty to 120 minutes after injection it was determined as $0.042-0.048 \%$. The last specimen taken 2.5 hours after insulin showed $0.037 \%$. The initial rate of adrenaline secretion from the right as well as from the left adrenal gland was found to be $0.02 \mu \mathrm{g}$. per kg. per minute. After insulin it was accelerated and reached $0.11 \mu \mathrm{g}$. in the left gland and $0.10 \mu \mathrm{g}$. in the right gland, respectively, the maximal acceleration being noted within 1.5 hours after injection. Then it decreased step by step. During the whole course no noticeable difference 
was found in the adrenaline secretion rate between the left and the right glands.

In Exp. 4 the blood sugar content before insulin was $0.115 \%$. It decreased gradually after insulin. One hour and a half after injection there was a low blood sugar level such as $0.045 \%$ and half an hour later it descended further, $0.038 \%$ being reached. The adrenaline secretion rate

TABLE II

Adrenaline Secretion Rate after Insulin in Dogs

Subjected to the Spinal Cord Hemisection

\begin{tabular}{|c|c|c|c|c|c|c|c|c|}
\hline \multirow{2}{*}{ 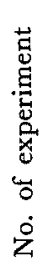 } & \multirow{2}{*}{ 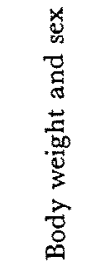 } & \multirow{2}{*}{ 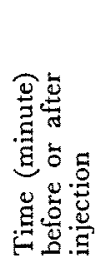 } & \multirow{2}{*}{ 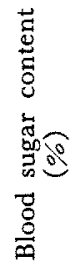 } & \multicolumn{2}{|c|}{ 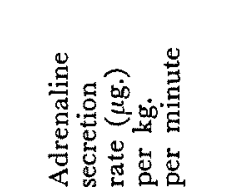 } & \multirow{2}{*}{ 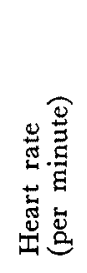 } & \multirow{2}{*}{ 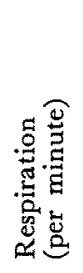 } & \multirow{2}{*}{ 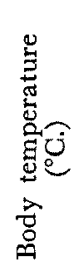 } \\
\hline & & & & $\begin{array}{l}\text { Right } \\
\text { gland }\end{array}$ & $\begin{array}{l}\text { Left } \\
\text { gland }\end{array}$ & & & \\
\hline \multirow[t]{2}{*}{3} & \multirow[t]{2}{*}{$\underset{\text { 우 }}{13.5 \mathrm{~kg}}$} & $\begin{array}{c}\text { Before } \\
25 \\
20 \\
10 \\
5\end{array}$ & $\begin{array}{l}0.124 \\
0.120 \\
0.122\end{array}$ & $\begin{array}{l}0.02 \\
0.02\end{array}$ & $\begin{array}{l}0.02 \\
0.02\end{array}$ & $\begin{array}{l}160 \\
176\end{array}$ & $\begin{array}{l}16 \\
18\end{array}$ & $\begin{array}{l}38.2 \\
38.3\end{array}$ \\
\hline & & $\begin{array}{c}\text { After } \\
20 \\
25 \\
40 \\
45 \\
60 \\
65 \\
90 \\
95 \\
120 \\
125 \\
150 \\
155\end{array}$ & $\begin{array}{r}\text { Inje } \\
0.078 \\
0.044 \\
0.018 \\
0.042 \\
0.044 \\
0.037\end{array}$ & $\begin{array}{c}\text { of ins } \\
0.04 \\
0.07 \\
0.08 \\
0.10 \\
0.08 \\
0.03\end{array}$ & $\begin{array}{l}0.06 \\
0.04 \\
0.06 \\
0.11 \\
0.06 \\
0.03\end{array}$ & $\begin{array}{c}\text { er kg.) } \\
184 \\
194 \\
192 \\
184 \\
186 \\
176\end{array}$ & $\begin{array}{l}16 \\
16 \\
20 \\
22 \\
18 \\
18\end{array}$ & $\begin{array}{l}38.3 \\
38.1 \\
37.8 \\
37.6 \\
37.5 \\
37.3\end{array}$ \\
\hline \multirow[t]{2}{*}{4} & \multirow[t]{2}{*}{$\underset{\$}{12.8 \mathrm{~kg} .}$} & $\begin{array}{l}\text { Before } \\
20 \\
15 \\
10\end{array}$ & $\begin{array}{l}0.115 \\
0.115\end{array}$ & $\begin{array}{l}0.03 \\
0.03\end{array}$ & $\begin{array}{l}0.02 \\
0.02\end{array}$ & $\begin{array}{l}136 \\
138\end{array}$ & $\begin{array}{l}16 \\
14\end{array}$ & $\begin{array}{l}38.3 \\
38.3\end{array}$ \\
\hline & & $\begin{array}{c}\text { After } \\
30 \\
35 \\
60 \\
65 \\
90 \\
95 \\
120 \\
125 \\
150\end{array}$ & $\begin{array}{l}0.070 \\
0.054 \\
0.045 \\
0.038 \\
0.036\end{array}$ & $\begin{array}{l}0.08 \\
0.08 \\
0.11 \\
0.43\end{array}$ & $\begin{array}{l}0.08 \\
0.06 \\
0.05 \\
0.19\end{array}$ & $\begin{array}{r}\text { er } \mathrm{kg} \\
144 \\
152 \\
156 \\
98 \\
142\end{array}$ & $\begin{array}{r}16 \\
18 \\
20 \\
8 \\
12\end{array}$ & $\begin{array}{l}38.2 \\
38.1 \\
37.9 \\
37.8 \\
37.9\end{array}$ \\
\hline
\end{tabular}




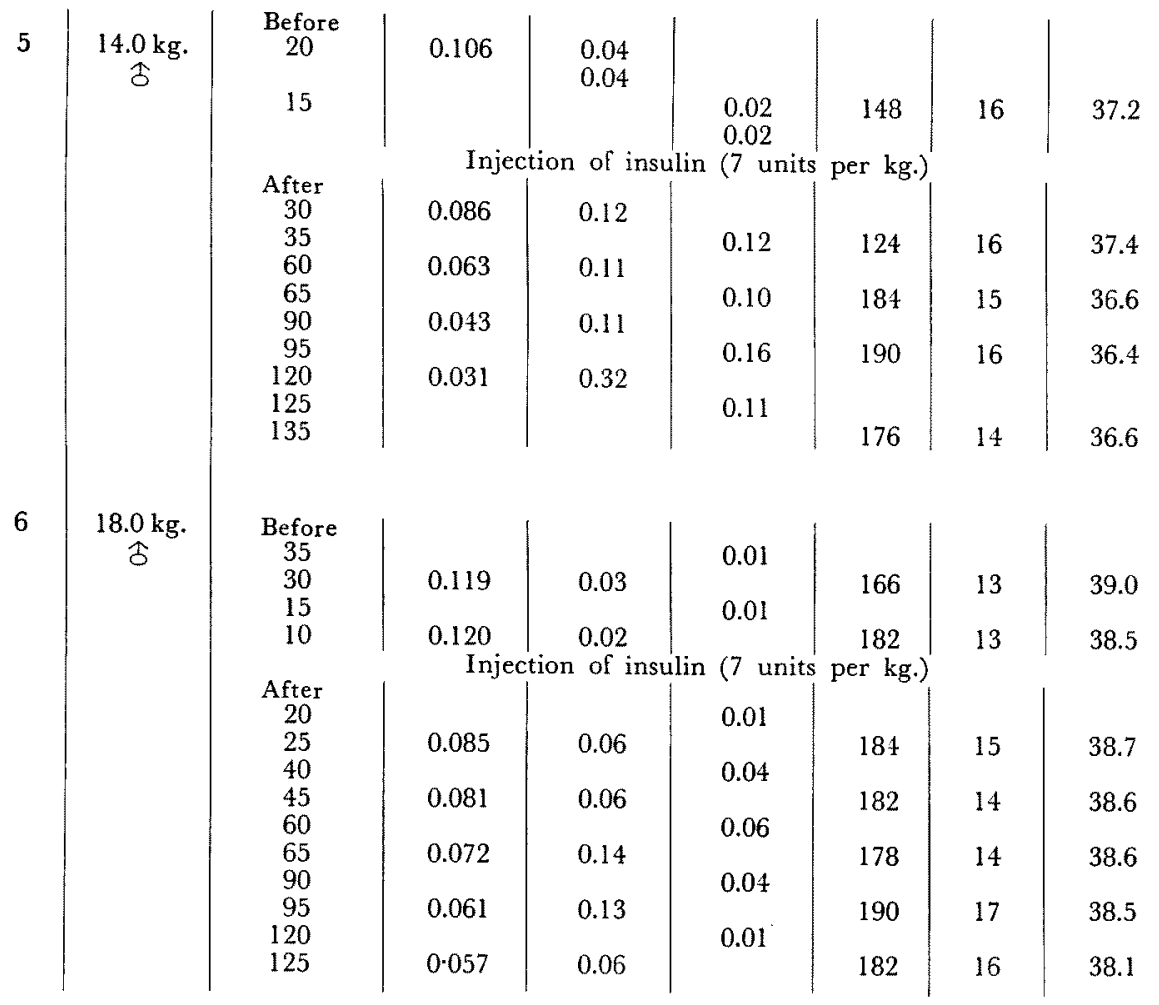

before insulin was $0.02 \mu \mathrm{g}$. per kg. per minute in the left and in the right adrenal gland. About 30 minutes after insulin the adrenaline secretion from the left as well as from the right adrenal gland was somewhat accelerated and reached $0.08 \mu \mathrm{g}$. One hour after insulin it was $0.06 \mu \mathrm{g}$. in the left and $0.08 \mu \mathrm{g}$. in the right gland, respectively, and 30 minutes later the secretion rate of the left gland was measured as $0.05 \mu \mathrm{g}$., whereas that of the right gland was $0.11 \mu \mathrm{g}$. Half an hour later it was found to be $0.19 \mu \mathrm{g}$. in the left and $0.43 \mu \mathrm{g}$. in the right gland, respectively.

In Exp. 5 the initial blood sugar content was $0.106 \%$. After insulin the level of blood sugar descended and $0.031 \%$ was reached within 2 hours after injection. The adrenaline secretion rate before insulin was $0.02 \mu \mathrm{g}$. per $\mathrm{kg}$. per minute in the left gland and $0.04 \mu \mathrm{g}$. in the right gland, respectively. Half an hour after injection it was found to be $0.12 \mu \mathrm{g}$. in the left as well as in the right gland. Half an hour and one hour later the secretion rate of adrenaline of the left gland was determined as $0.10 \mu \mathrm{g}$. and $0.16 \mu \mathrm{g}$., respectively. And that of the right gland was measured as $0.11 \mu \mathrm{g}$. About 2 hours after insulin the rate of adrenaline secretion of the left gland was $0.11 \mu \mathrm{g}$., whereas that of the right gland was $0.32 \mu \mathrm{g}$. 
In Exp. 6 the blood sugar content before insulin was found to be $0.119-0.120 \%$. After insulin it decreased gradually. About 2 hours after insulin it reached $0.057 \%$. The adrenaline secretion rate before insulin was $0.01 \mu \mathrm{g}$. per $\mathrm{kg}$. per minute in the left gland and $0.02-0.03 \mu \mathrm{g}$. in the right gland. After insulin it increased and reached $0.06 \mu \mathrm{g}$. in the left and $0.14 \mu \mathrm{g}$. in the right gland, the maximum being found within one hour after insulin.

\section{Discussion}

Evidence provided by Sato et al. was confirmed in the first series of experiments. Insulin hypoglycemia was proved to induce an increase in the adrenaline secretion by acting the adrenalino-secretory center situated above the lower cervical segments. Hence, if the descending spinal pathway of adrenalino-secretory fibers runs directly without crossing, the hemisection of the spinal cord may nullify the increase in the adrenaline secretion causable by insulin hypoglycemia only of the ipsilateral adrenal. And if it decussates completely below the lower cervical segments, the increase may be observed only in the ipsilateral gland. However, neither of them has turned out to be the case. In our experiments the adrenaline secretion was found to be increased by insulin hypoglycemia in the ipsilateral as well as in the contralateral gland, though it was mostly somewhat less pronounced in the former than in the latter.

Thus, it may be reasonable to conclude that in dogs the descending spinal pathway of the adrenalino-secretory fibers decussates partially in the spinal cord below the cervical segments.

\section{SummaRY}

The experiments were performed in unanesthetized dogs. The adrenal venous blood was sampled by the lumbar route method of Satake and others and was assayed for adrenaline by the rabbit intestinal segment method. The following results were obtained: The increase in the adrenaline secretion causable by insulin hypoglycemia was found to be wholly abolished by the total section of the spinal cord at the level of C7C8. In dogs subjected to the hemisection of the spinal cord at the same level as above, the adrenaline secretion was increased by insulin hypoglycemia in the contralateral as well as in the ipsilateral adrenal gland.

It is concluded that the descending spinal pathway of the adrenalinosecretory fibers decussates partially below the lower cervical segments.

\section{References}

1) Tournade, A., Hermann, H., Malmejac, J. \& Jourdan, F., Ann. Physiol., 1931, 7, 233.

2) Sato, H., Kanowoka, Sh. \& Ohmi, F., Tohoku J. Exper. Med., 1933, 22, 7.

3) Satake, Y., Sugawara, T. \& Watanabe, M., ibid., 1927, 8, 501. 